$$
1, \Lambda-(3)=-82-3656
$$

DER 3 COOA744

\title{
TITL: Flow Cytometric Quantification of Radiation Responses of Murine Peritoneal Cells
}

AUthoR(S): N. 1 ta and :1. R. Raju

SUBMITted to: Proceedings of the International Symposium on Blologfcal Dosimetry, Oct 14-l6, 1982 Neherberg, F.R.G. 


\title{
FLOW CYTOMETRIC QUANTIFICATION OF RADIATION RESPONSES \\ OF MURINE PERITONEAL CELLS
}

\author{
N. Tokita and M. R. Raju \\ Life Sciences Division, Los Alamos National Laboratory \\ University of California, Los Alamos, NM 87545 USA
}

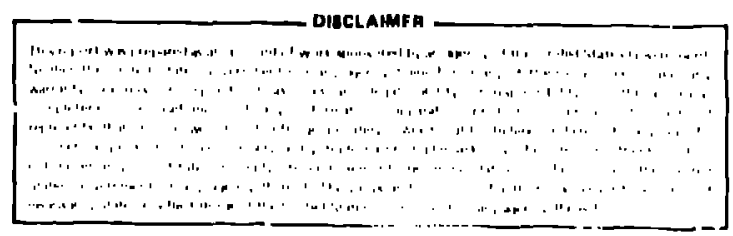

- This work was supported by Grant CA 22585 from the National Cancer Institute, U. S. DHEW and by the U.S. Department of Energy. 
All correspondence should be addressed to:
N. Tokita
LS- 1 MS-M880
Los Alamos National Laboratory
Los Alamos, NM 87545 USA 


\section{ASBTRACT}

Methods have been developed to distinguish subpopulations of murine peritoneal cells, and these were applied to the measurement of early changes in peritoneal cells after irradiation. The ratio of the two majur subpopulations in the peritoneal fluid, lymphocytes and macrophages, was measured rapidly idy ineans of cell vclume distribution analysis as well as by hypotonic propidium iodide (PI) staining. After irradiation, dose and time dependent changes were noted in the cell volume distributions: a rapid loss of peritoneal lymphocytes, and an increase in the mean cell volume of macrophages. The hypotonic PJ staining characteristics of the peritoneal cells showed two or three distinotive $G$ peaks. The ratio of the areas of these peaks was also found to be denendent on tha radiation dose and the time after 1rfidiation. These results demonstrate that these two parameters may be used to monitor changes induced by j.rradiation (biological dosimetry), and to sort. alfierent peritoneal subpopulat lons.

kity words: Flow cytometiy, biological dosimetry, x rays, peritoncal colls. macrophages, I ymphocytes 


\section{INTRODUCTION}

Quantification of radiat. on resporise is the basis for biological dosimetry. The conventional dosimeters $u$ ied for low-LET irradiation have been peripheral 1 ymphocyte counting and chromosome aberration enumeration. More recently, other dosimetric methods have also been reported, e.8., dosimetry based on spermatogenesis (Hacker et al. 1980) and on peripheral reticulocyte counting (Chaudhuri et al. 1979). The study of chromosome aberrations in peripheral 1 ymphocytes provides an average dose estimate within a few days and has been used clinically (Purrot et al. 1972; Doloy et al. 1977).

The development of flow cytometry has made 1t possible to measure biological parameters rapidly and with a high degree of statistical accuracy. This technology has been applied to the field of biological dosinetry (Carrano et al. 1978: Hacker et al. 1980). In an attempt to shorten the assay period, i.e., oblaining results within 24 hours after exposure, and to make the assay Independent of circulating 1 ynphocytes, we have measured the radiation responses of mouse peritoneal cells using flow cytometry. Two major subpopulations, 1 imphocytes and macrophages, exist in the peritoneal cavity of mice (Felix and Dalton 195\%; Coodinan 1964: Balner 1963). Several studles have shown that the number of peritoneal 1 ymphocytes was reduced after Irradiation, while the maseringe population remalnod relatively unchanged (Balner i963; Bercovic1 and Ciraham 1964; Kornfeld and Groenmun 1966). Because of cell size differences botwoen 1 ymphoeytes and maerophages (Folix and Dalton 195l; Kornfeld and (ircenun 1966) and our proliminary date indlesting difrerent propidium lodide

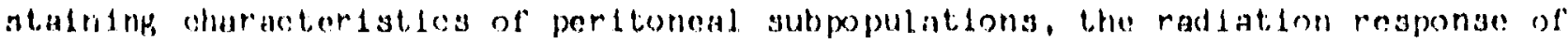

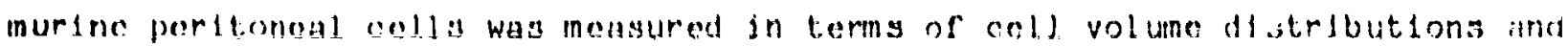

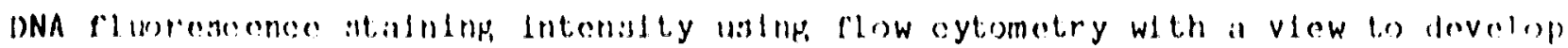
a rapld iloloploul dosimetry syotion. 
MATERIALS AND METHODS

Mice (strain CD-1, female, 8-12 weeks old, Charles River Laboratories) were used for this study. Six to ten mice were used per dose point. Whole body irradiation of mice was carried out with $x$ rays (GE Maxitron, $50 \mathrm{keV}, 30 \mathrm{~mA}, 2$ $\mathrm{mm} \mathrm{Cu} \mathrm{HVL,} \mathrm{a} \mathrm{dose} \mathrm{rate} \mathrm{of} 2 \mathrm{~Gy} / \mathrm{min}$ ) through a single portal. At various times after irradiation, $8 \mathrm{ml}$ of al pha IEM medium (Grand Island Biological Company) containing 5 USP units per $\mathrm{ml}$ of sodium heparin and $190 \mathrm{mM}$ morpholinopropanesulfonic acid (Sigma Chemical Company) at $37^{\circ} \mathrm{C}$ was injected intraperitoneally. Approximately 15 min after i.p. injecition, the mice were sacrificed and the fluid removed from the peritonial cavity. The average number of cells obtained from unirradiated mice was $6-8 \times 10^{6}$ cells, while the total number of cells obtained from the peritoneal cavity of irradiated mice decreased depending on the radiation dose and time after irradiation. After pipetting repeatedly, aliquots of the cell slispension were used for cell counting using a hem $e^{2}$ ytometer or an electronic cell counter (Coulter Electronics). Cell volume distriblicion analyses were performed with the addition of a pulse height analjzer to the coulter cointer. The remaining cells were centrifuged at 3008 for $5 \mathrm{~min}$. Part of the cells were used for histological staining; the remaining ceil.t were fixed in $70 \%$ ethanol for $30 \mathrm{~m} 1 \mathrm{n}$ at $4^{\circ} \mathrm{C}$. The ethanol-f1xed c..11s were stained with a hypotonic propidium lodide solution containing $50 \mu \mathrm{g} / \mathrm{ml}$ propldium lodide (Sigma) ind $1 \mathrm{mg} / \mathrm{ml}$ sodium citrate in distilled water. This is a inodification of the staining procedure of Crissman and Steinkainp (1973) and of Kr1shan (1975). The moasurement of PI fluorescence as well as cell sorting were performed on flow cytometers avaliable at Los Alamos using an arpon-1on laser operating, at $488 \mathrm{~nm}$ and the appropriate fllters and detectors (Holm and Cram 19'3; stounkamp ot al. 19'i3!. 
RESULTS

The cell volume distributions of peritoneal ceils measured 12 hours after 0 to $11 \mathrm{~Gy}$ of $x$ rays are shown in Figure 1 . Cells from each peak in the control were sorted onto slides and histological observations demonstrated that the small and large volume populations corresponded to iymphocytes and macrophages respectively. As the radiation dose was increased, the fraction of the cells in the first peak decreased progressively as a result of a rapid loss of peritoneal lymphocytes. The number of macrophages remained unchanged within 24 hrs after Irradiation.

Figure 2 shows the cell volume distributions of peritoneal vells measurad 24 hours after 0 to 8 Gy of $x$ rays. In addition to the changes in the relative areas of the two peaks, there is a shift of the second peak towards larger cell volumes at 5 and $8 \mathrm{~Gy}$. A cytological examination revealed that the macrophages obtalned from mice receiving 8 Gy appeared 20-30\% larger than those from unirradiated mice. There werc also an increased number of granulocytes in the peritomeal cavity of Irradiated mise.

In order to quantitate the changes in peritoneal ccll subpopulations after

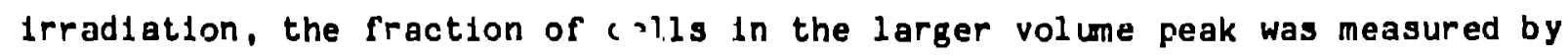
dividing the two populatioris at their inflection point and calculating the rraction of cells above the infleution point as a peroent of the total population. Flgure 3 shows the percent of the population contalned in the sarge volume peak plotted as a function of radiation dose. The reiative lnorease in the raction of celis in the second pouk was Jimllar at 12 and 24 hourg after irradiution. However, the reletive iricrosse in seoond poak fiaction was enhanced at 18 hours.

When cthanol-fixel peritoncal cells were slallled with hypotonic PI solution without RNase, two or three peaks were sbservod in lic $G_{1}$ fillorascenco intensity resion. Fibure " shows the lluorescence Intensity of the PI-stained peritoneal ceils 2"l hrs after irradiation. Both of the two promincht peak. in tho control correspond to $i_{1}$ rluorescence Intensity penks. Cell sorting of tho two populations onto alldes followed by mlerosesple oximination indleated thili tho colls In the Lewor fluuroscence Intchsicy peak appesarod to be mostly jymphocytas Ilonk with somn granulocytas, whoroas the unlls comprlzing the highor flimrnaconce Litionatty peak were macrophikes with somn larbe lymphocytos. As 
the radiation dose was increased, the first peak area also decreased. Figure 5 shows the $G_{1}$ fluorescence intensity distributions of PI-stained cells collected 0 to 8 days after a single dose o: $5 \mathrm{~Gy}$. The relative second-peak area increased with longer times after irradiation.

The fraction of cells in the higher $G_{1}$ fluorescence intensity peak was estimated by the same method described for volume distributions and plotted as a function of radiation dose. Figure 6 shows the dose-response patterns measured at various times after irradiation. There is no significant change noted in the fraction of cells in the lower sluorescence intensity peak when the cells were sampled betwesn 12 to 48 hours after irradiation. 
DISCUSSION

There were two types of changes noted in the cell volume distributions of peritoneal cells after irradiation: (1) a shift in the ratio of small to large cells due to a rapid loss of lymphocytes, and (2) an increase in the mealı cell volume of macrophages seen 24 hours after irradiation. The rapid loss of peritoneal lynphocytes after Irradiation has been well docunented (Balner 1963; Bercovicl and Graham 1963; Kornfeld and Greenman 1966). The Increase in cell volume seen only after higher doses (Figure 2) is significant. Geiger and Gallily (19/3) observed numerous invaginations or "holes" on the olter surfaces of Irradiated macropilages. It is not known whether the increase in size observed in our study is an artifact caused by suspending the cells in medium. Metcal $f$ et al. (1977) reported that mouse bone marrow progenitors of Branulocytes and macrophages increased In size 2 days after 2.5 Gy whole body Irradiation and that all subpopulations vere affected. In our study, however, the size increase appeared limited to the macrophage population.

The multimodal $G_{1}$ fluorcscence intensity observed after PI staining of peritoneal cells indicates that staining characteristics differ for various types of cells even though the cells had been fixed in ethanol prior to taining. When the cells obtained at 0-8 days after irradiation ( 0 to 11 Gy) were stained with the method described by $\mathrm{Kr} 1$ shan (1975), In which RNase was also added, no multimodal $G_{1}$ rluorescence Intensity peaks were observed. The CV value for the $G_{1}$ peak was rather $h 1 \mathrm{gh}(4-5 \%)$, however, and no cells were found with S-phase DNA contents (data not shown). Since the PI solution used in this study stains double-stranded RNA in adaition to DNA (Crissman and Steinkamp 1973), the differences in double-stranded RNA content between the two subpopulations might have contributed to the separation of the control $G_{1}$ cells into distinct fluorescence intensity pcaks. The changes in the relative size of the muitimodal $G_{1}$ peaks of irradiated peritoneal cells appear to have been calised primarily by alterations in the cell populations. Gelger and Gallily (1974) reported that Irradjation of macrophage donors caused activation " severas macrophage functions, Including a 3ix-fold Increase in RNA synthusis. It is yet to be determined if such an Increase in RNA synthesis in Irradiated macrophages has al so affected the multimodal $G$, cluorescence intensity pattern seen in this atudy. 
The results demonstrate that cell volune distributions as well as hypotonic PI staining may be used to monitor changes induced by irradiation (biological dosimetry), and to sort different peritoneal subpopulations. 
ACKNOWLEDGEI:ENTS

The authors thank Mark Wilder for his assistanne in cell sorting studies and Elvira Bain for computer graphics. W are also indebted to James P. Freyer. James F. Jett and Anita Stevenson for their comments and advice. 
REFERENCES

1. Balner H (1963) IJentification of peritoneal macrophages in mouse radiation chimera. Transplantation 1: 217-223.

2. Bercovici B, Graham RM (1964) The immediate effects of local radiation on the cells in the peritoneal cavity of mice. Radiat Res 7: 129-138.

3. Crissinan HA, Steinkamp JA (1973) Rapid, simuiaterieous measurement of DNA, protein and cell volume in single cells for large mamalian cell populations. J Cell Biol 59: 766-771.

4. Chaudhuri JP, Metzger E, Messerschmit 0 (1979) Peripheral reticulocyte count as biologic dosimetry of ionizing radiation. Acta Radiol Oncol 18: 155-160.

5. Doloy MT, LE GO R, Ducatez G, Lepatit J, Bourguignon M (1977) Utilisation des analyses chromosomiques pour l'estimation d'uns d'irradiation accidentalle chez l'horme. Proc 4th Int Congr II.PA, Paris, 4: 1199-1204.

6. Felix MD, Dalton AJ (1955) A phase-contrast microscope study of free cells native to the peritoneal fluid of $\mathrm{DBA} / 2 \mathrm{mice}$. $\mathrm{J}$ Nat Cancer Inst 16: 415-428.

7. Gelger B, Gallily $R$ (1974) Effeci of $x$-1rradiation on various functions of murine macroph sges. Clin exp Immunol 16: 643-655.

8. Geiger B, Gallily R (1974) Surfacc morphologs of irradiated macrophages. J Reticuloendothel Soc 15: 274-231.

9. Goodman JW (1964) On the origin of peritoneal fluid cello. Blood 23: 18-26.

10. Hacker U, Schumann J, Gohde W (1980) Effects of acute gamma-1rradiation on spermatogenesls as revealed ty flow cytometry. Acta Radiol Oncol 19: $361-368$. 
11. Holm DM, Cram LS (1973) An improved flow microfluorometer for rapid measurement of cell fluorescence. Exp Cell Res 80: 105-109.

12. Kornfeld L. Greenman V (1966) Effects of total-body X-irradiation on peritoenal cells of mice. Radiat Res 29: 433-444.

13. Krishan A (1975) Rapid flow cytofluorometric analysis of mammalian cell cycle by propidium iodide stainng. J Cell Biol 6E: 188-193.

14. Purrot RJ, Lloyd DC (1972) The study of cnromosome aberration yield in human Iymphocytes as an Indicator of radiation dose. I. Techniques, Rep. NRPB-R2.

15. Steinkamp JA, Fulwyler MJ, Coulter JR, Hiebert RD, Horney JL, Mullaney PF (1973) A new multifarameter separator for microscopic particles and biological cells. Rev Sci Instr 44: 1301-1310. 


\section{FIGURE LEGENDS}

Figure 1. Cell volume distributions of murine peritoneal cells obtained 12 hours after irradiation. The cells comprizing the small and large volumes peaks in the control population correspond to 1 mphocytes and macrophages. respectively.

Figure 2. Cell volume distributions of peritoneal cells obtained 24 hours after 0 to $8 \mathrm{~Gy} x$-irradiation. The cell volume distributions of cells taken after single doses of 5 and 8 Gy show an increase in the mean cell volume of macrophages.

Figiare 3. The fraction of cells in the second peak of each cell vilume distribution expressed as a percent of the totai population plotted as a function of radiation dose.

Figure 4. Propidium lodide staining characteristics of $G$ peritone-l cells taken $24 \mathrm{hrs}$ after irradiation.

Figure 5. Propiólum lodide staining characteristics of peritoneal cells taken 0 to 8 days after a single dcse of 5 Gy.

Figure 6. The fraction of cells in the high rlunrescence intensily peak as a percent of the total population plotted as a function of dese. 
$12 \mathrm{HR}$

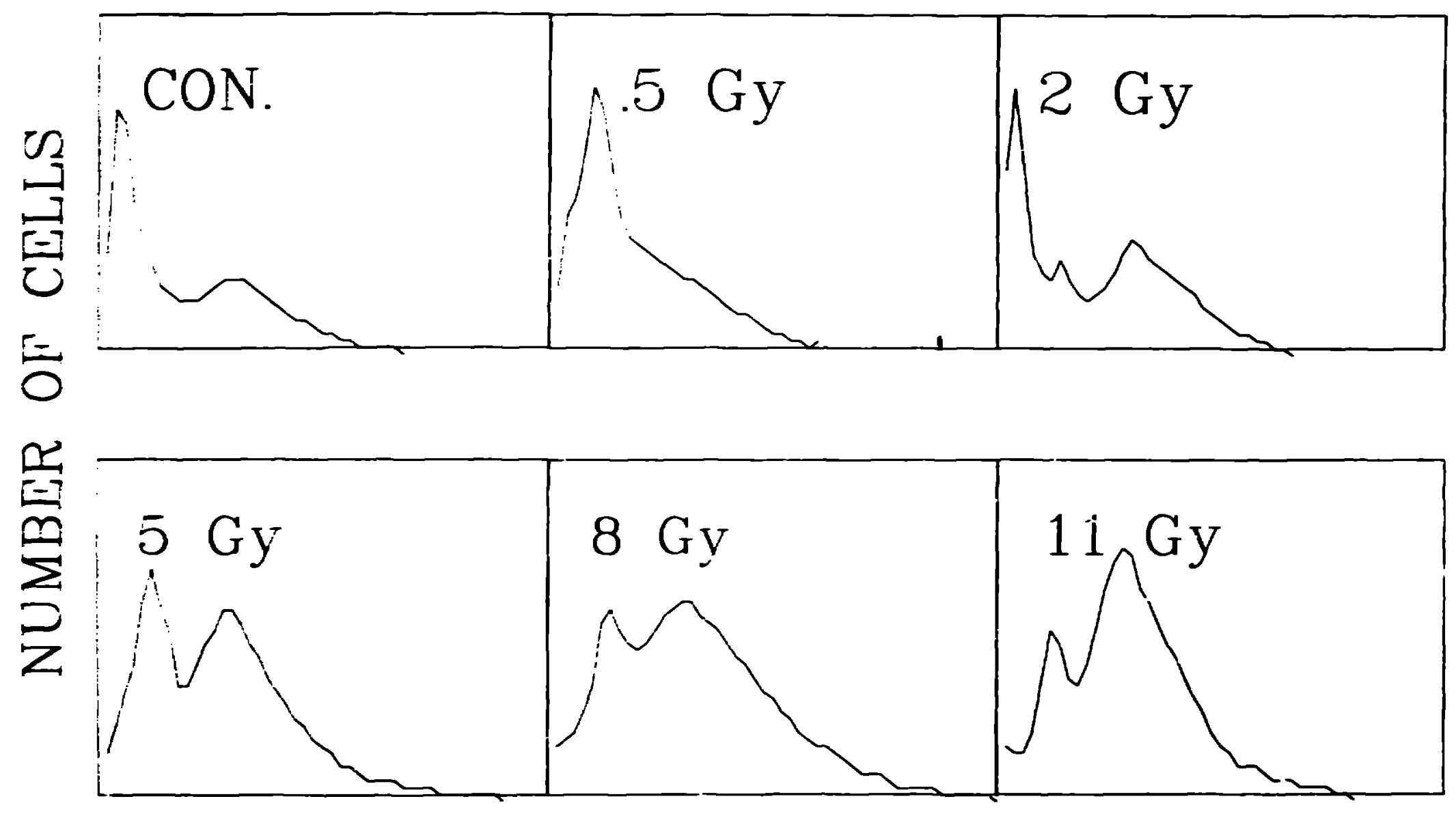

COULTER VOLUME 


\section{$\underline{24} \mathrm{HR}$}
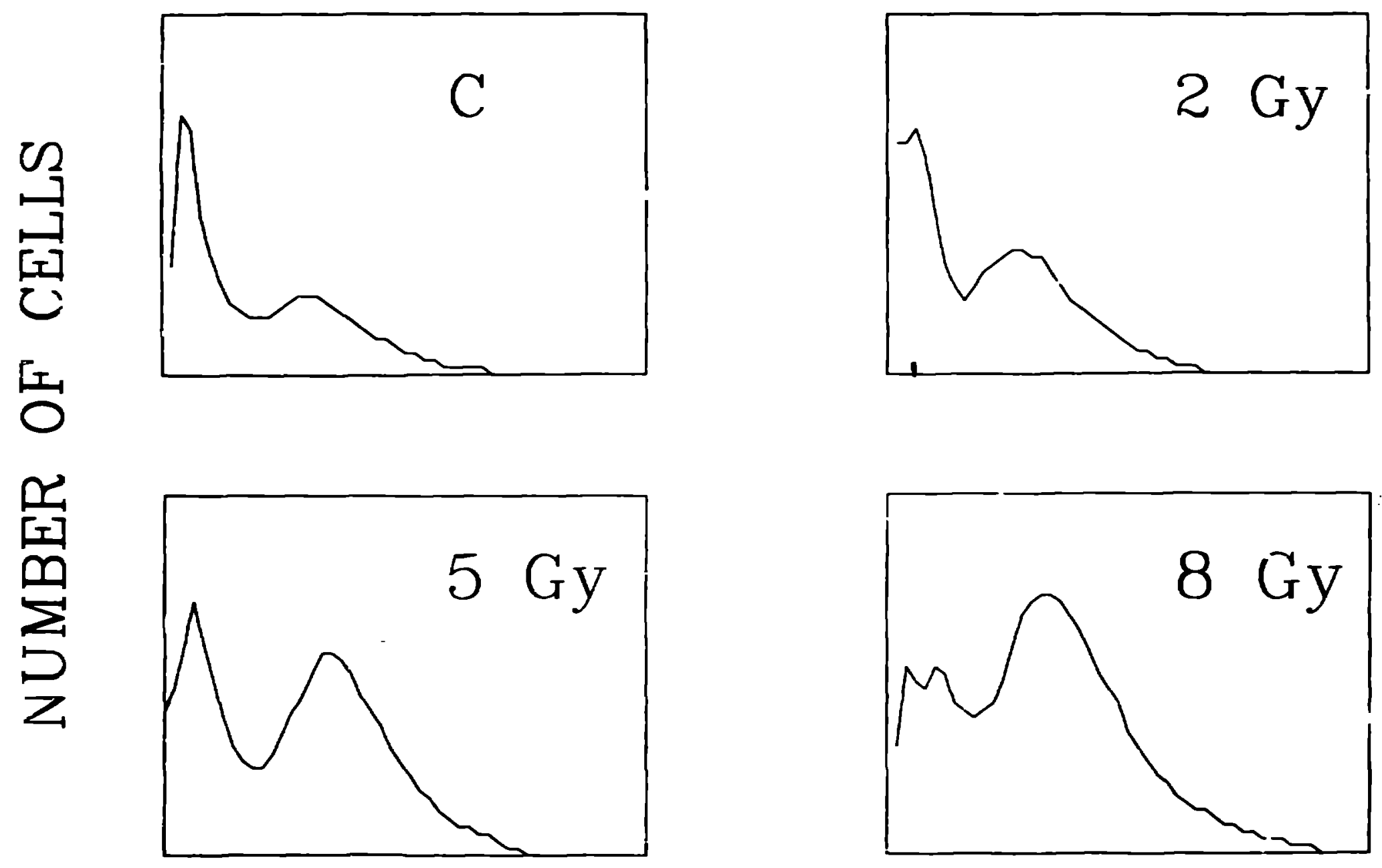

COULTER VOLUME 


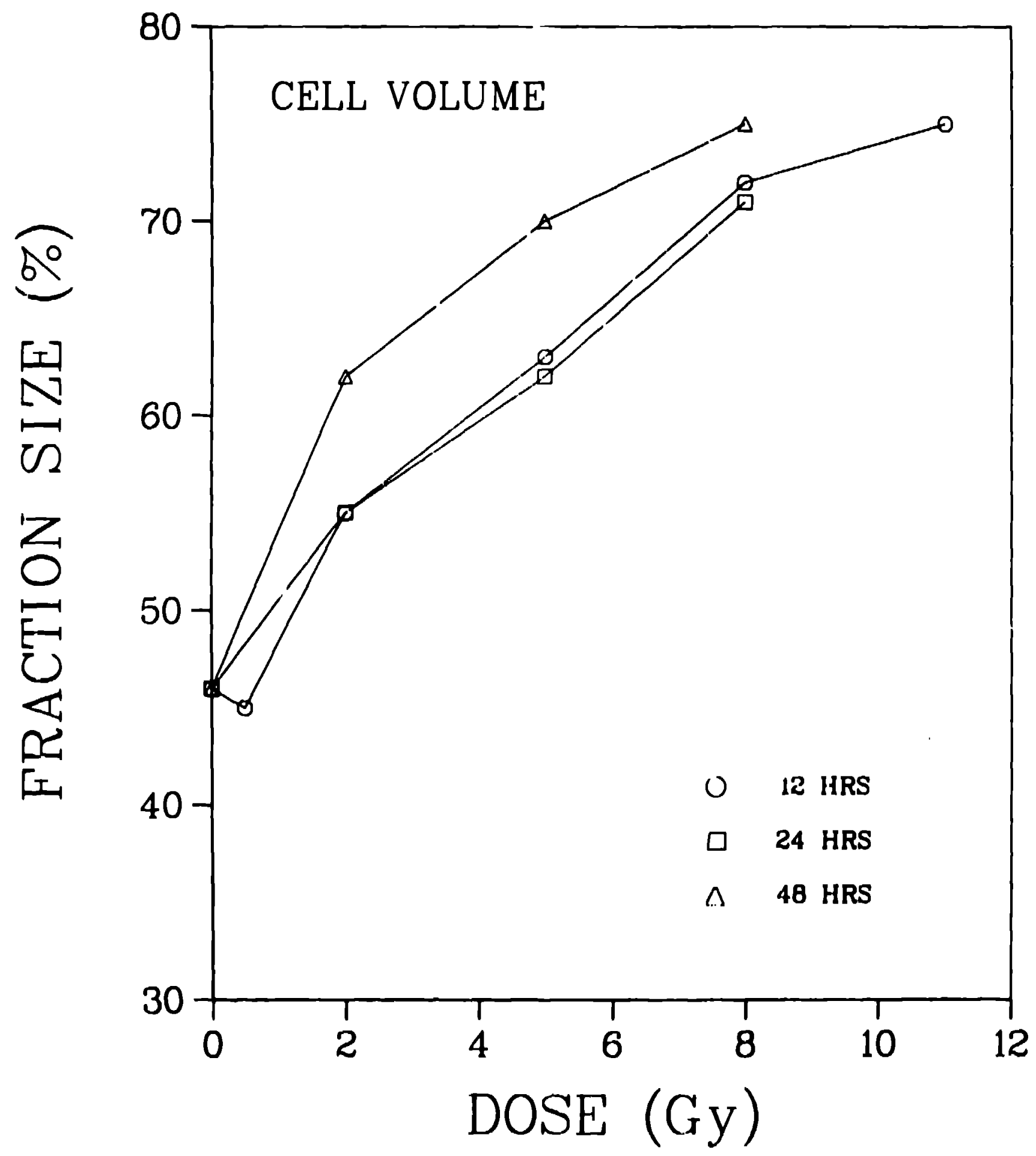



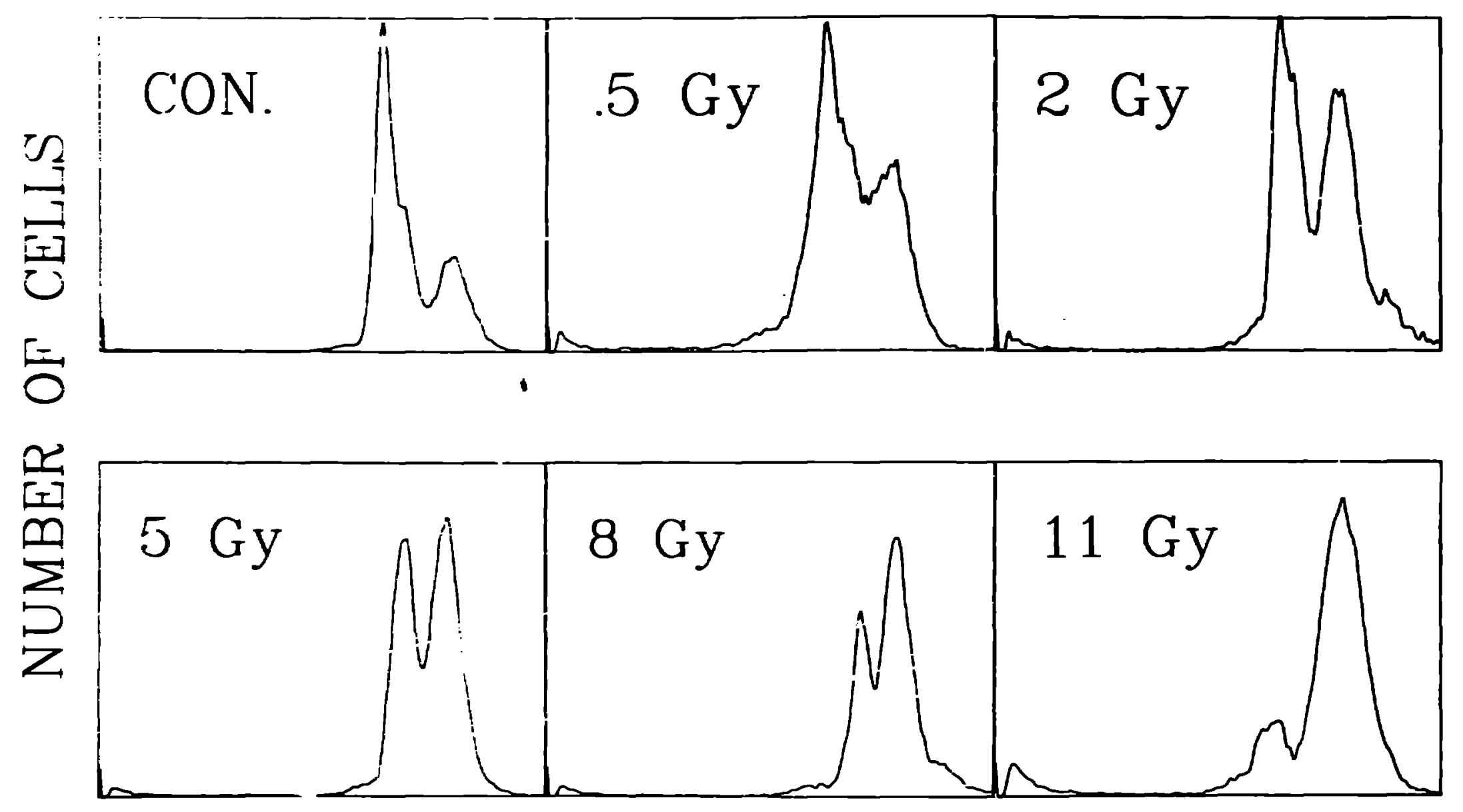

FLUORESCENCE 
$\underline{5 \mathrm{~Gy}}$
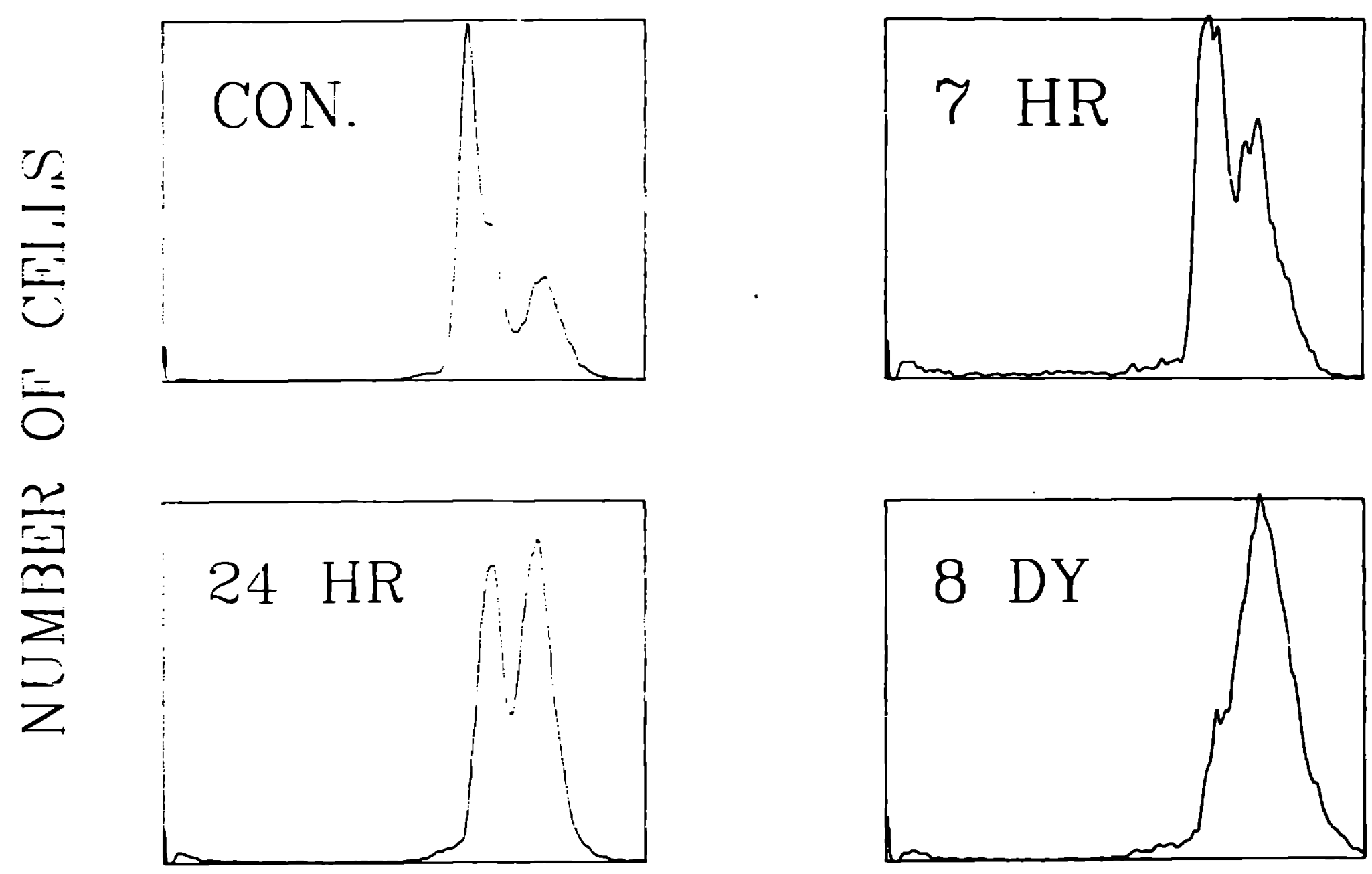

FLUORESCENCE 


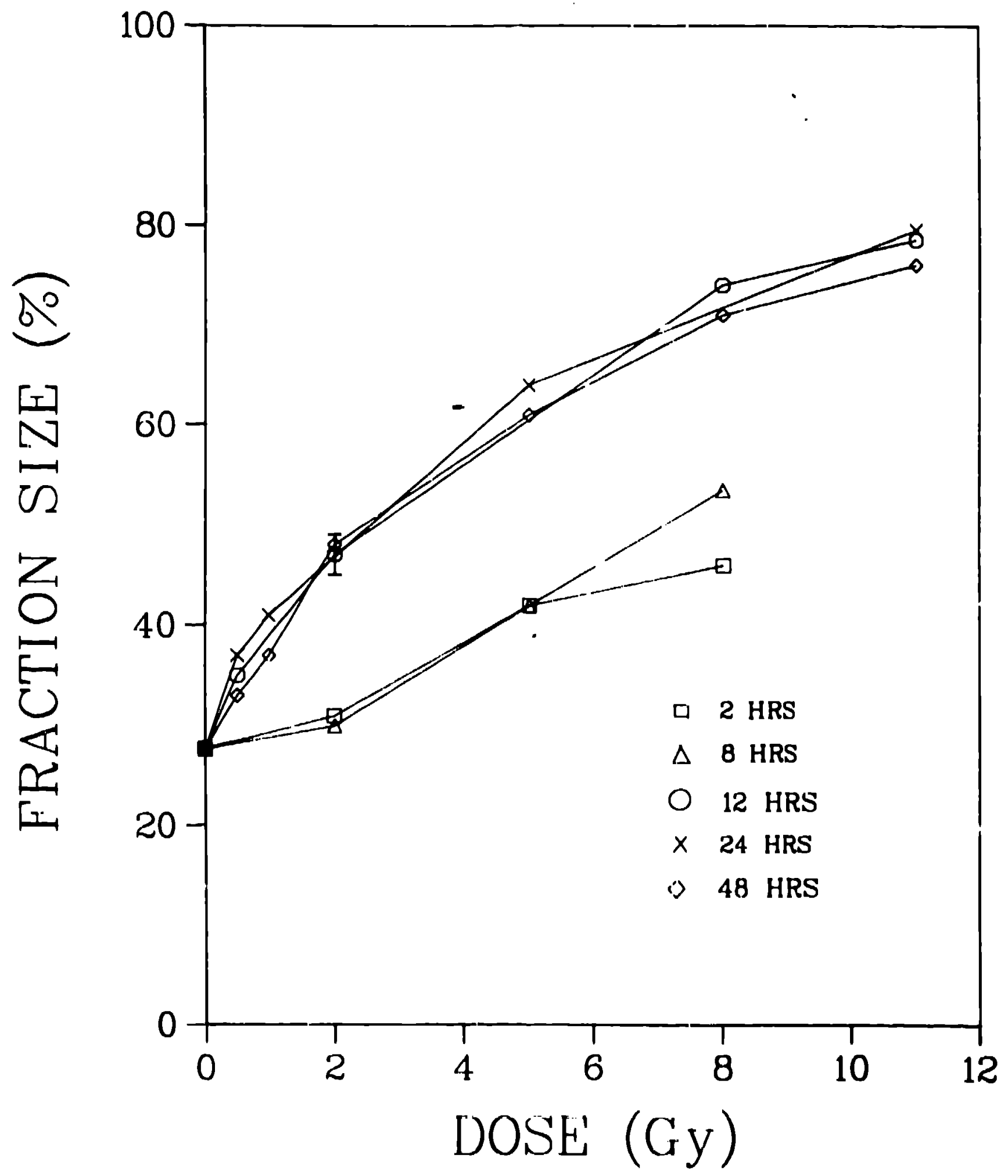

